\title{
Ecological assessment of a coastal shallow lagoon in Lagos, Nigeria: A bio-indicator approach
}

\author{
*BALOGUN, K J; LADIGBOLU, I A; ARIYO, A A \\ Nigerian Institute for Oceanography and Marine Research, P.M.B. 12729, Victoria Island, Lagos, Nigeria
}

\begin{abstract}
Benthic macro-invertebrates of the Northern axis of metropolitan segment of Lagos Lagoon sediments, Nigeria were investigated for six months (April - September, 2010). The study was aimed at using benthic macro-invertebrates to assess the water quality of this part of the Lagoon. A total of ten taxa belonging to three major animal phyla from a total of 2,672 individuals were encountered. The dominant taxa throughout the study and stations were Pachymelania aurita, Aloidis trigona, and Neritina glabrata. Station A (Ikorodu port) had seven taxa, station B (Ibese) had five while stations C (Ofin) and D (Oreta) had eight taxa each. Stations A(Ikorodu port), B(Ibese), C(Ofin) and D(Oreta) accounted for $8.19 \%, 0.94 \%, 79.83 \%$ and $11.04 \%$ respectively in all the individuals collected. Gastropoda was highest and accounted for $54.83 \%$ of all individuals collected from all stations contributing $2.58 \%$ at station $\mathrm{A}$ and $0.49 \%, 48.39 \%$ and $3.37 \%$ respectively at stations B, C and D, while Polychaeta had the least $(0.97 \%)$ with station A, B, C and D constituted $0.82 \%$, $0.04 \%, 0.04 \%$ and $0.07 \%$ respectively. Sediment type of the study areas was predominantly muddy sand. The presence of more pollution tolerant species (Nereis spp, Capitella capitata and Polydora ciliata) in station A may serve to confirm that the community has been impacted by pollution. The low faunal abundance and diversity observed in station B could be attributed to stress imposed by effluents from industrial sources. The information of this study will be very useful in formulating policies and regulatory framework for sustainable management of Lagos Lagoon. @ JASEM
\end{abstract}

Benthic macro-invertebrates include crustaceans such as crayfish, mollusks such as clams and snails, aquatic worms and the immature forms of aquatic insects such as stonefly and mayfly nymphs. These organisms form a major link in the food chain as most estuarine and marine fishes, birds and mammals depend directly or indirectly on the benthos for their food supply (Barnes and Hughes, 1988). Benthic macro-invertebrates can be used as indicators of water quality. These organisms play a critical role in the natural flow of energy and nutrients because of their abundance and position as "middlemen" in the aquatic food chain. Some important factors governing the abundance and distribution of macro-invertebrate benthic communities according to Dance and Hynes, (1980) include water quality, immediate substrates for occupation and food availability. Any ecological imbalance arising from any severe alterations of these factors may affect the macro-benthos.

Coastal lagoon ecosystems serve as pollution filters and are of important traditional value to local people, yet they have become targets of destructive exploitation in recent times. Discharge of domestic and industrial effluents and sand mining activities are some of man's actions which undermine the ecological integrity of lagoon ecosystem. Many lagoons in West Africa presently required biodiversity restoration and conservation measures, which call for periodic species survey. Benthic macro-invertebrates community is widely used for detection and monitoring of man's impact on aquatic ecosystems.

Various scientists (Webb and Hill, 1958; Sandison, 1966; Yoloye, 1969; Oyenekan, 1975; Ajao, 1990, Ajao and Fagade, 1990; Brown, 1991) have worked on the ecology of macrobenthic communities within the lagoon system. However, there is a dearth of information on the assessment of the coastal lagoon water quality with the use of bio-indicator.

This study was aimed at using the structure and spatial distribution of benthic macro-invertebrates of the Northern axis of metropolitan segment of Lagos Lagoon to assess the water quality of this part of the Lagoon.

\section{MATERIALS AND METHODS}

Study Area: The study was carried out in the metropolitan segment of Lagos Lagoon complex (Fig. 1). Lagos lagoon with an area of $208 \mathrm{~km}^{2}$ is located between latitude $6^{\circ} 26^{\prime} \mathrm{N}$ and $6^{\circ} 38^{\prime} \mathrm{N}$ longitude $3^{\circ} 23^{\prime} \mathrm{E}$ and $3^{\circ} 43^{\prime} \mathrm{E}$ (Fig. 1). The lagoon is shallow with an average depth of $1.5 \mathrm{~m}$ except at the channels that are dredged occasionally (Webb, 1958). It opens into the gulf of Guinea through the Lagos harbour which is the only opening to the sea for the entire western lagoons of Nigeria. The lagoon sediments range between mud, sandy mud, muddy sand, and sand (Ajao and Fagade, 1990). Artisanal fishers within the lagoon mainly exploit the fisheries using wooden/dug-out canoes ranging in size from 3 to $8 \mathrm{~m}$ long. The canoes are either paddled or powered by small outboard engines, and manned by an average of two men. From these boats, the fishers operate their cast nets, hook and lines, gillnet, stownets traps, liftnets, longline, basket traps etc (Solarin, 1998; Emmanuel et al., 2008a). 


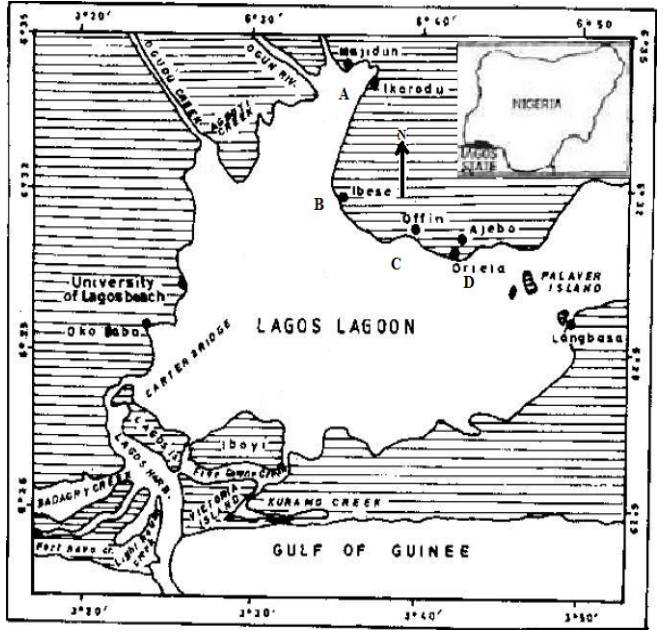

Fig 1: Map of Lagos Lagoon Showing Sampling Stations in Alphabet A, B, C \& D

Table 1: Stations sampled in the Lagos Lagoon with coordinates.

\begin{tabular}{|c|c|c|c|}
\hline Stations & Station Name & N-Coordinates & E- Coordinates \\
\hline$\overline{\mathbf{A}}$ & Ikorodu port & N06 $^{0} 36.032^{\prime}$ & $\mathrm{E}^{\prime} 003^{0} 28.835^{\prime}$ \\
\hline B & Ibese & $\mathrm{N}^{0} 6^{0} 32.116^{\prime}$ & $\mathrm{E} 003^{0} 29.534^{\prime}$ \\
\hline $\mathbf{C}$ & Ofin & N06 ${ }^{0} 32.309^{\prime}$ & $\mathrm{E} 003^{0} 30.003^{\prime}$ \\
\hline D & Oreta & N06 ${ }^{0} 31.954$, & $\mathrm{E} 003^{0} 30.664^{\prime}$ \\
\hline
\end{tabular}

Sample collection: Sampling for benthic macroinvertebrates was carried out in four study stations chosen along the Northern axis of the metropolitan segment of Lagos Lagoon complex at monthly interval between April and September 2010. Stations sampled with their coordinates are presented in Table 1 .

Sediment and Benthic Macro-invertebrates: Bottom sediments for the analysis of benthos were collected with a Van veen grab sampler $\left(0.1 \mathrm{~m}^{2}\right)$ in each of the four stations. At each sampling station, the grab was dropped from the edge of an outboard engine boat and then hauled up into the boat. Composite sediment samples was collected from each station and put into labeled polythene bags for sediment analysis.

On deck, each sample was empty into a plastic bowl and water was added to dissolve the sediment. Thereafter, it was gently stirred and carefully sieve through a $0.5 \mathrm{~mm}$ mesh sieve (Mclntyre et al., 1984). The content of the sieve after washing was transferred into a pre-labeled container and $10 \%$ formalin (with Rose Bengal stain) added as preservative (Eleftheriou and Holme, 1984) for further analysis for benthic macro-invertebrates in the laboratory.

Laboratory analysis for benthic Macro-invertebrates samples: In the laboratory, a little of the sieved and fixed samples was taken into the white enamel tray at a time and painstakingly sorted with the aid of the magnifying lens for clearer vision. The sorted samples from each sampling station were then put in a transparent glass bottle and preserved with 5\% formalin. These are known as the clean samples. The organisms were later identified to their lowest taxonomic group and counted. Identification was done with the aid of relevant guides and texts by Olaniyan (1968), Edmunds (1978), Barnes (1980), Fischer et al. (1981), Hayward and Ryland (1995), Yankson and Kendall (2001).

Sediment Analysis: Sediment particle size analysis was done using the method described by Brown (1991), and total organic matter determined by the rapid ash method employed in Oyenekan (1975).

Statistical Analysis: All statistical methods used were adapted from Ogbeibu (2005). Macrobenthic community structure was estimated using the Margalef's species richness index (d) (Margalef, 1951); Shannon-Weiner information function (AS) (Shannon and Weaver, 1949) and Equitability index or Evenness (Lloyd and Ghellardi, 1964).

The Species richness index (d) according to Margalef (1951) was used to evaluate the community structure.

$$
d=\frac{s-1}{\ln N}
$$

Where: $d=$ Species richness index; $S=$ Number of species in a population; $N=$ Total number of individuals in species.

Shannon and Wiener diversity index (Hs) (Shannon and Weiner, 1949) which Ogbeibu, (2005) presented as

$$
H s=\frac{N \log N-E P i \log P i}{N}
$$

Where: $H s=$ Shannon and Wiener diversity Index; $i=$ Counts denoting the $i t h$ species ranging from $1-n ; P i$ $=$ Proportion that the ith species represents in terms of numbers of individuals with respect to the total number of individuals in the sampling space as whole.

Species Equitability or Evenness index (j) (Ogbeibu, 2005). The Species Equitability or Evenness index (j)

$$
J=\frac{H z}{\log _{2} g}
$$

Where: $J=$ Equitability index; Hs = Shannon and Weiner index; $\mathrm{S}=$ Number of species in a population;

Simpson's dominance index (C) (Ogbeibu, 2005).

$$
C=\Sigma\left(\frac{n i}{N}\right)^{2}
$$

Where: $C=$ dominance index; $n=$ the total number of organisms of a particular species; $N=$ the total number of organisms of all species. 


\section{RESULTS AND DISCUSSION}

The bottom deposits of the study areas of the Lagoon varied between sand and muddy sand. Soil $\mathrm{pH}$ was alkaline in nature in all the study stations and ranged from 7.38 to 7.60 while the total organic matter
(TOM) ranged from $16.58 \%$ to $19.03 \%$ in the study area (Table 2). There were no significant differences ( $p>0.01)$ in values of TOM between sampling stations.

Table 2: Physico-chemical characteristics of sediments of the study stations in Lagos Lagoon (Values are: Mean \pm SD)

\begin{tabular}{|l|l|l|l|l|}
\hline parameters & Station A & Station B & Station C & Station D \\
\hline Soil pH & $7.38 \pm 0.13$ & $7.40 \pm 0.28$ & $7.53 \pm 0.10$ & $7.60 \pm 0.27$ \\
\hline Organic Matter (\%) & $17.82 \pm 4.50$ & $16.58 \pm 3.58$ & $19.03 \pm 3.41$ & $17.05 \pm 2.75$ \\
\hline \multicolumn{4}{|c|}{ (Station A - Ikorodu port, B - Ibese, C - Ofin, D - Oreta) }
\end{tabular}

Table 3: Spatial composition, distribution and abundance of benthic macro-invertebrates of study stations in Lagos Lagoon

\begin{tabular}{lllllll}
\hline Class/Group & species & Station A & Station B & Station C & Station D & Total \\
\hline Bivalvia & Aloides trigona & 128 & 11 & 495 & 47 & 681 \\
Bivalvia & Mytilus edulis & - & - & 9 & - & 9 \\
Crustacea & Balanus pallidus & - & - & 335 & 156 & 491 \\
Gastropoda & Tympanotonus fuscata & 20 & - & 6 & 40 & 66 \\
Gastropoda & Pachymelania aurita & 27 & 7 & 764 & 33 & 831 \\
Gastropoda & Neritina glabrata & 22 & 4 & 131 & 3 & 160 \\
Gastropoda & Neritina senegalensis & - & 2 & 392 & 14 & 408 \\
Polychaeta & Nereis spp & 8 & - & 1 & 1 & 10 \\
Polychaeta & Capitella capitata & 12 & 1 & - & 1 & 14 \\
Polychaeta & Polydora ciliata & 2 & - & - & - & 2 \\
& No of Spp/Station & 7 & 5 & 8 & 8 & 10 \\
& No of individual/Station & 219 & 25 & 2133 & 295 & 2672 \\
\hline
\end{tabular}

(Station A - Ikorodu port, B - Ibese, C - Ofin, D - Oreta)

The composition, abundance and distribution patterns of species in the study areas are presented in Table 3 . Ten taxa belonging to 3 major animal phyla were identified from a total of Two thousand, six hundred and seventy-two individuals collected. The animal phyla recorded were Annelida, Mollusca, and Arthropoda. The more dominant taxonomic groups were mollusca. The phylum mollusca, annelid and arthropoda constituted six, three and one taxa respectively. The gastropod mollusca include Tympanotonus fuscatus, Pachymelania aurita, Neritina glabrata and Neritina senegalensis, while the bivalvia mollusca include Aloidis trigona, and Mytilus edulis. The annelids were Nereis spp, Capitella capitata and Polydora ciliata. The arthropoda was represented by Balanus pallidus. Of all the taxa recorded, Aloidis trigona, Pachymelania aurita and Neritina glabrata were encountered in all the study stations. The ten taxa belonging to four classes and three phyla of benthic macro invertebrates encountered in the study reveals reduction in the species diversity as compared with earlier reports (Oyenekan, 1988; Ajao and Fagade, 1990; Akpata et al., 1993; and Brown \& Oyenekan, 1998). A total of forty-two species of benthic macro fauna were collected from the Lagos lagoon during the wet and dry seasons by Ajao and Fagade (1990), Williams (1999) recorded fifteen benthic species at Oworoshoki portion of the lagoon while Emmanuel et al., (2010) reported twenty species in Acdja fishing sites in the Lagoon. The differences in species composition recorded could be attributed to the ecological differences of the different geographical locations. The low benthic macro-invertebrate community abundance, composition and diversity recorded in this study may be attributed to stress imposed by indiscriminate anthropogenic activities in the lagoon. Ajao et al. (1996) identified sand mining, sand filling, industrial effluent discharge, oil wastes, domestic waste, sewage discharges among others as human related activities capable and presently destroying the sensitive coastal environment of Nigeria species. Pachymelania aurita (Gastropoda) was the most abundant taxa recorded in the study areas while Polydora ciliata (Polychaeta) was the least abundance taxa recorded. The Pachymelania community encountered in all the stations studied was a reflection of the sand and muddy sand nature of the sediment. Oyenekan (1988) in the study of benthic macro-faunal communities in the Lagos 
lagoon reported that the Pachymelania community is characterized by sand and muddy sand deposit. Nominate member include T. fuscatus, A. trigona, $N$. glabrata, Nereis sp., $P$. aurita among others. According to Brown, (1998) Salinity and sediment type would seem to be the more important factors controlling the community structure and variability. However, in spatial distribution and abundance (Table 3), Station A had seven taxa, station B had five while stations $\mathrm{C}$ and $\mathrm{D}$ had eight taxa each. Stations A, B, C and D accounted for $8.19 \%, 0.94 \%$, $79.83 \%$ and $11.04 \%$ respectively in all the individuals collected. The class abundance trend of benthic macro invertebrates in sediment of the study areas is presented in Figure 2. Gastropoda was highest and accounted for $54.83 \%$ of all individuals collected from all stations contributing $2.58 \%$ at station $\mathrm{A}$ and $0.49 \%, 48.39 \%$ and $3.37 \%$ respectively at stations B, $\mathrm{C}$ and $\mathrm{D}$ as revealed in Figure 3, while Polychaeta had the least $(0.97 \%)$ with station $\mathrm{A}, \mathrm{B}, \mathrm{C}$ and D constituted $0.82 \%, 0.04 \%, 0.04 \%$ and $0.07 \%$ respectively. The relative abundance of benthic macro-invertebrates in each of the study stations is an indicative of the level of impact of each station. Out of the ten taxa recorded in this study, mollusca comprising Gastropoda (54.83\%) and Bivalvia(25.82\%) dominated the species abundance. The present of Gastropoda (Pachymelania aurita and Neritina glabrata) in high density in station $\mathrm{C}$ suggests that the station was relatively less impacted by pollution. Brown and Oyenekan (1998) had earlier reported Pachymelania aurita and Neritina glabrata as pollution sensitive species. The polychaeta (Nereis sp., Capitella capitata and Polydora ciliata) were more abundant in station A. This may be indicative of organic enrichment. Ajao and Fagade (1990) reported that the Polychaetes: Capitella capitata, Nereis sp., and Polydora sp. were found associated with sites grossly polluted with organic matter, heavy metals and petroleum hydrocarbons. Brown and Oyenekan (1998) also suggested that $P$. ciliata could be as opportunistic as Capitella capitata, a universal indicator of organic pollution. This group of organisms is known as opportunistic and tolerant species for they thrive in oxygen depleted sediments where others find difficult to survive.

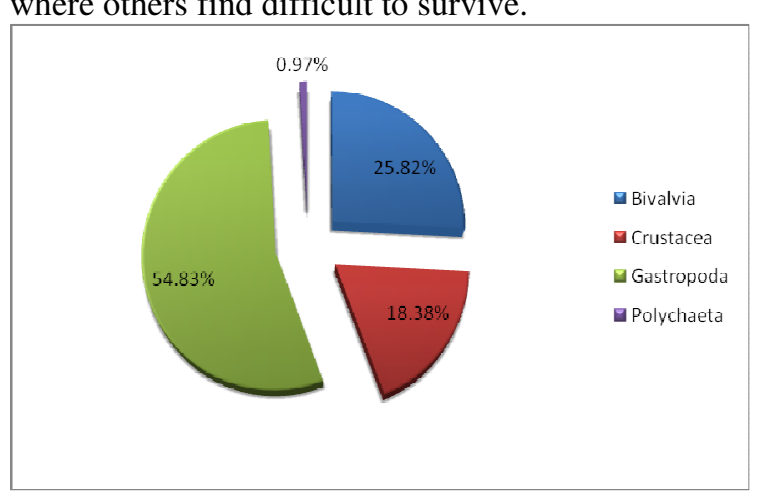

Fig 2: Class Abundance of Benthic macro-invertebrate of the study areas in Lagos Lagoon.

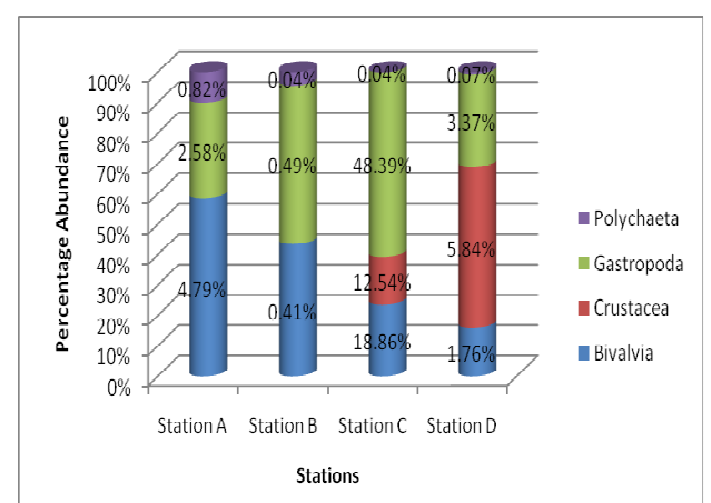

Fig 3: Relative abundance of major benthic macro-invertebrates of the study areas in Lagos Lagoon.

Table 4 show the BMIs community structure of the study stations. The species richness (d) was highest in station B and lowest in station C, while station D had higher species richness than station $\mathrm{A}$. The species diversity measured by Shannon and Weaver diversity index $(\mathrm{H})$ however was highest in station $\mathrm{C}$ and lowest in B. The Evenness Index (E) in the study stations ranged from 0.661 in station $D$ to 0.833 in station B while Dominance Index (C) ranged from 0.245 in station $\mathrm{C}$ to 0.379 in station $\mathrm{A}$. The reduction in the benthic macro-invertebrates abundance and diversity in station $\mathrm{B}$ (Ibese) with five species and a total of twenty-five individuals may be due to devastating effects on the ecological balance of the aquatic environment caused by complex industrial effluents received in this station from industrial establishments on the shore. The low Shannon's Diversity indices of this station may be a further indication of the impact of the perturbation stress on the benthic macro-invertebrate community.

Conclusion: An ecosystem ecological state could be assessed by the abundance, distribution and diversity of the benthic macro-invertebrates. Benthic macroinvertebrates represent an extremely diverse group of aquatic animals, and possess a wide range of responses to pollution. In this study, the presence of more tolerant species (Nereis spp, Capitella capitata and Polydora ciliata) in station A (Ikorodu port) may serve to confirm that the station was organically polluted. However, low density of Polychaetes (pollution indicator species) and more abundant of mollusca and crustacea (pollution sensitive species) in station C (Ofin) and D (Oreta) indicated relatively healthy communities. 
Table 4: Community structure analysis of the study areas in Lagos Lagoon

\begin{tabular}{lllll}
\hline & Station A & Station B & Station C & Station D \\
\hline Log of Species diversity (Log S) & 0.845 & 0.699 & 0.903 & 0.903 \\
Log of abundance (Log N) & 2.34 & 1.398 & 3.329 & 2.47 \\
Species Richness/Margalef Index (d) & 1.113 & 1.243 & 0.913 & 1.231 \\
Shannon-Wiener Index (H) & 0.584 & 0.582 & 0.662 & 0.597 \\
Equitability/Evenness Index (j) & 0.691 & 0.833 & 0.733 & 0.661 \\
Dominance Index (C) & 0.379 & 0.306 & 0.245 & 0.338 \\
Simpson's Index (D) & 0.368 & 0.3303 & 0.242 & 0.334 \\
\hline \multicolumn{2}{c}{ (Station A - Ikorodu port, B - Ibese, C - Ofin, D - Oreta) }
\end{tabular}

(Station A - Ikorodu port, B - Ibese, C - Ofin, D - Oreta)

Acknowledgement: The authors are grateful to the Nigerian institute for oceanography and marine research, Nigeria, for the use of her facilities. We would also like to thank the Director of Biological Oceanography department of the Institute Dr. E. O. Oyewo for his guidance and encouragement.

\section{REFERENCE}

Ajao EA (1990). The influence of domestic and industrial effluents on populations of sessile and benthic organisms in Lagos Lagoon. PhD Thesis, University of Lagos p. 411.

Ajao, E.A. and Fagade, S.O. (1990). Study of the sediments and communities in Lagos lagoon, Nigeria. Oil and Chemical Pollution. 7: 85-117, Elsevier Science Publishers Ltd., England.

Ajao, E.A., Oyewo, E.O. and Uyimadu, J.P. (1996): A review of the pollution of coastal waters in Nigeria. Nigerian Institute for Oceanography \& Marine Research Technical Paper No. 107. 20pp.

Akpata, T.V.I.; Oyenekan, J.A. and Nwankwo, D.I. (1993). Impacts of Organic Pollution on the Bacterial, Plankton and Benthic populations of the Lagos Lagoon Nigeria. International Journal of Ecology and Environmental Sciences. 19: $73-$ 82.

Barnes, R.D. and S. Hughes, (1988). An introduction to marine ecology. 2nd Edn., Blackwell Scientific Publications, UK., pp: 351.

Barnes, R.D., (1980). Invertebrate Zoology. 4th Edn., W.B. Saunders, Philadelphia, pp: 1089.

Brown, C. A. (1991). Community Structure and Secondary Production of Benthic Macrofauna of the Lagos Lagoon and harbour M. Phil Thesis University of Lagos 359pp.

Brown, C. A. and Oyenekan, J. A. (1998). Temporal variability in the structure of benthic macrofauna communities of the Lagos Lagoon and harbour, Nigeria. Pol. Arch. Hydrobiol. 45(1): 45 - 54.

Brown, C.A.(1998). Distribution and population dynamics of an estuarine population of Aloidis trigona Hinds (Bivalvia).Acta Hydrobiol. 40(4): $227-237$.

Dance, K. W. and Hynes HBN. (1980). some effects of agricultural land use on stream insect communities. Environ Pollut Ser A. 1980: 22; 19 -28 .

Edmunds, J., (1978). Sea Shells and Other Molluscs Found on West African Shores and Estuaries. Ghana University Press, Accra, pp: 148.

Eleftheriou, A. and N.A. Holme, (1984). Macrofauna Techniques. In: Methods for the Study of Marine Benthos, Holm, N. A and McIntyre (Eds.). Blackwell Scientific Publications, USA., pp: 140- 216.

Emmanuel, B E, Chukwu, L. O and Bakare, S. O (2010). Hydro-Chemistry, Macro-Invertebrate Fauna And Fish Production Of Acdja Fishing Sites In A Tropical Lagoonal Ecosystem Journal of American Science 2010;6(1):42-48

Emmanuel, B.E., Chukwu, L.O. and Azeez, L.O. (2008a). Cast net design characteristics, catch composition and selectivity in tropical open lagoon. African Journal of Biotechnology.7 (12): $2081-2089$.

Fischer, W., G. Bianchi and W.B. Scott, (1981). FAO species identification sheets for fisheries purposes. Eastern Central Atlantic: Fishing Areas 34 and Part of 47. Food and Agriculture Organization of the United Nations.

Hayward, P.J. and J.S. Ryland, (1995). Handbook of the Marine Fauna of North-East Europe. Oxford University Press, New York, pp: 591. 
Lloyd, M. and Ghellardi, R. G. (1964). A table for calculating the equitability components of species diversity. J. Anim. Ecol. 33: 217-225.

Margalef, D.R. (1951). Diversidad de especies en les communideades natural Public Institutte of Biologic Barcelonia 9 : 5- 27.

Margalef, D.R. (1951). Diversidad de especies en les communideades natural Public Institutte of Biologic Barcelonia $9: 5-27$

McIntyre, A.D., J.M. Elliot and D.V. Ellis, (1984). Introduction: Design of Sampling Programmes. In: Methods for the Study of Marine Benthos, Holme, N.A. and A.D. McIntyre (Eds.). Blackwell Scientific, Oxford, pp: 1-26.

Ogbeibu, A.E., (2005). Biostatistics: A practical approach to research and data handling. Mindex Publishing Co. Ltd., Benin, Nigeria, ISBN: 9788035-81-7, p. 264.

Olaniyan, C.I.O., (1968). An Introduction to West African Animal Ecology. Heinemann Education Books Ltd., Ibadan, pp: 165.

Oyenekan, J.A. (1988): Benthic macrofaunal communities of Lagos Lagoon, Nigeria. Nig. J. Sci. 21: $45-51$.

Oyenekan, J.A., (1975). A survey of the Lagos lagoon benthos (with particular reference to the molluscs). M.Sc. Thesis. University of Lagos.
Sandison, E. E. (1966). The effect of salinity fluctuations on the life cycle of Balanus pallidus strutburi Darwin in Lagos harbour, Nigeria. J. Anim. Ecol., 35, 363-378.

Shannon CE, and Wiener W. (1949). The Mathematical Theory of Communication Urban. University of Illinois Press; 125.

Solarin, B.B. (1998) Hydrobiology, fishes and fisheries of the Lagos Lagoon, Nigeria. PhD Thesis, University of Lagos. 256pp.

Webb, J. E. (1958). The ecology of Lagos Lagoon. 1. The lagoons of the Guinea coast. Phil. Trans. Roy. Soc. Lond., 683 (241), 307 - 318.

Webb, J. E. and Hill M. B. (1958). The ecology of Lagos lagoon. 4. On the reactions of Branchiostoma nigeriense. Phil. Trans. Roy. Soc. Lond., 683 (241), 355 - 391.

Williams, A.B., (1999). Ecological studies of macrobenthic fauna of the light house creek and oworonsoki areas of Lagos Lagoon. M.Sc Thesis, University of Lagos, pp: 97

Yankson, K. and M. Kendall, 2001. A student guide to the sea shore of West Africa. Darwin Initiative Report 1, pp: 132.

Yoloye, V.L. (1969). On the biology of the West African Bloody cockle Anadara (Sanilia) senilis L Ph.D. Thesis University of Ibadan Nigeria. 